\title{
PENGARUH TEKNIK TOTAL QUALITY MANAGEMENT TERHADAP KINERJA MANAJERIAL DENGAN SISTEM PENGUKURAN KINERJA DAN SISTEM PENGHARGAAN SERTA PERILAKU MANAJER SEBAGAI VARIABEL MODERATING
}

\author{
Tita Boedi Astuti ${ }^{1}$ \\ ${ }^{1}$ STIE Malangkucecwara Malang \\ titabudi@gmail.com
}

\begin{abstract}
Total Quality Management (TQM) is a technique to improve the performance of an organization either profit or non-profit on an ongoing basis at each level of the organization or process in each functional area in an organization by using all the HR and capital owned. In the era of globalization, every company must face an increasingly competitive situation with the increasing number of competitors and requires companies to always be able to understand the needs and desires of customers and try to fulfill them in ways that are superior to those of competitors. So that in this globalization process every organization is always responsive to change. Data collection is carried out on each variable as a value of each respondent and the data analysis method uses statistical calculation regression analysis model where the coefficient value of TQM along with the performance measurement system has a positiv effect.

Keywords: Performance Measurenent, Total Quality Management

\section{ABSTRAK}

Total Quality Management (TQM) merupakan suatu tehnik untuk meningkatkan performa suatu organisasi baik profit atau non profit secara berkelanjutan pada setiap tingkatan organisasi atau proses dalam setiap wilayah fungsional dalam suatu organisasi dengan menggunakan semua SDM serta modal yang dimiliki. Dalam era globalisasi setiap perusahaan harus menghadapi situasi persaingan yang semakin kompetitif dengan semakin banyaknya pesaing dan menuntut perusahaan harus selalu mampu memahami kebutuhan serta keinginan pelanggan dan berusaha memenuhinya dengan cara yang lebih unggul daripada yang dilakukan pesaing. Sehingga dalam proses globalisasi ini setiap organisasi untuk selalu tanggap terhadap perubahan. Pengumpulan data dilakukan pada setiap variabel sebagai suatu value dari tiap-tiap responden dapat dan metode analisa data menggunakan perhitungan statistic model analisis regresi dimana nilai koefisien TQM beserta sistem pengukuran kinerja yang berpengaruh positif.
\end{abstract}

Kata Kunci: Pengukuran Kinerja, Total Quality Management 


\section{PENDAHULUAN}

Di dalam melaksanakan aktivitasnya, suatu perusahaan memerlukan beberapa faktor produksi yang memiliki saling berkaitan antara satu dengan yang lainnya, yaitu faktorfaktor sumber daya alami, teknologi, modal dan sumber daya manusia. Keempat faktor tersebut harus bekerja sama dan dikelola dengan baik agar perusahaan memperoleh hasil yang maksimal. Dari berbagai faktor-faktor pendukung produktivitas kerja yang ada. Sumber daya manusia (SDM) adalah salah satu faktor yang mempengaruhi efektifitas pencapaian tujuan organisasi. Pada sumber daya manusia inilah semua pelaksanaan fungsifungsi dan tugas-tugas diserahkan, baik itu secara langsung maupun secara tidak langsung dalam usaha pencapaian tujuan organisasi yang seefektif mungkin. Oleh karena itu perusahaan harus meningkatkan kinerja para karyawannya. Salah satu cara untuk meningkatkan kinerja karyawan dapat ditempuh dengan menerapkan teknik TQM. Dengan diterapkannya teknik TQM dapat membantu meningkatkan kepuasan konsumen, kepuasan karyawan dan produktivitas sehingga karyawan dapat lebih terpacu di dalam mengidentifikasi berbagai teknik guna meningkatkan proses kegiatan pemanufakturan serta mampu untuk mereduksi tingkat kerusakan serta memastikan bahwa operasionalisasi perusahaan berjalan secara efisien dan lebih berorientasi pada kualias produk serta kepuasan pelanggan bukan produksi massa (Banker dan Schroeder, 1993). Dengan demikian filosofi TQM membuat karyawan untuk lebih bertanggung jawab di dalam mengontrol mutu serta penghentian kegiatan produksinya ketika terjadi permasalahan dalam operasionalisasi serta mendorong mereka untuk mengidentifikasi berbagai upaya untuk memperbaiki kualitas produk maupun proses. Dengan menggunakan Komponen-komponen berupa penerapan sistem pengukuran kinerja dan sistem penghargaan serta perilaku manajer, karena kinerja yang ditunjukkan oleh para anggota organisasi akan berpengaruh terhadap pencapaian tujuan suatu organisasi secara menyeluruh (Rifa'i, 2009).

Teknik pemanufakturan TQM dengan sistem pengukuran kinerja lebih sering digunakan guna mengupayakan peningkatan kinerja organisasi. Sistem pengukuran kinerja disini adalah frekuensi pelaporan pengukuran kinerja pemanufakturan karyawan di dalam mengembangkan efektivitas pekerjaan strategis. Semakin sering frekuensi pelaporan pengukuran kinerja suatu perusahaan berarti menunjukkan bahwa sistem untuk pengukuran kinerja pada perusahaan tersebut adalah baik, sehingga dapat membantu karyawan di dalam melaksanakan pekerjaan strategis dengan lebih cepat dan hal ini dapat digunakan untuk upaya meningkatkan kinerjanya. Program peningkatan kualitas dengan menerapkan teknik TQM dapat dikatakan efektif jika suatu perusahaan telah melakukan implementasi berbagai cara untuk memperbaiki kualitas secara kontinyu. Proses peningkatan kualitas ini akan mengalami peningkatan jika pembagian informasi dinyatakan dalam pembagian pekerjaan, sehingga dapat dikatakan bahwa pengukuran kinerja manajerial akan memberikan timbal balik dalam bentuk upaya pengendalian strategis yang dapat mendorong kepada para manajer untuk melakukan evaluasi serta menguji kembali tentang bagaimana komponen-komponen dalam TQM mampu meningkatkan pencapaian profitabilitas dalam usaha secara memadai. Frekuensi umpan balik kinerja dan tingkat pembelajaran karyawan akan meningkat jika karyawan menerima pengukuran kinerja non keuangan.

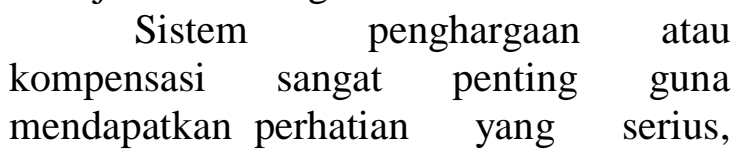
karena melalui pemberian kompensasi berupa berbagai insentif baik secara individual ataupun secara kelompok dapat 47| P a g e 
untuk meningkatkan prestasi kerja serta dapat memotivasi karyawan. Pada praktik pemanufaktuiran TQM yang lebih berorientasi pada upaya untuk melakukan kegiatan pemberdayaan karyawan, desain sistem kompensasi adalah merupakan salah satu bentuk metode yang penting untuk mencapai keberhasilan penerapan praktik pemanufakturan TQM. Dengan demikian, karyawan yang mempunyai kontribusi atau memberikan informasi yang bermanfaat untuk peningkatan mutu seharusnya menerima penghargaan dari manajemen. Perilaku manajer juga diperlukan dalam meningkatkan motivasi serta prestasi kerja dari karyawan dalam praktik pemanufakturan TQM. Manajer dan karyawan masing-masing memiliki sejumlah kepentingan dan nilai-nilai yang memerlukan suatu keseimbangan yang harus diterapkan diantara sesama mereka. Manajer akan dapat menarik dan mempertahankan karyawan-karyawannya yang baik dengan metode membangun hubungan dengan karyawan, sehingga dapat mencapai keberhasilan penerapan praktik pemanufakturan TQM.

Beberapa penelitian akuntansi sebelumnya menunjukkan kinerja suatu perusahaan yang rendah disebabkan karena perusahaan mengalami kegagalan di dalam menentukan berbagai sasaran atau tujuan yang tepat, berbagai upaya pengukuran kinerja, serta berbagai sistem model penghargaan maupun sistem penghargaan (Kaplan, 1983; Banker et. al . 1993). Menurut Ittner dan Larcker (1995), semakin besar pengukuran kinerja non keuangan dan pemberian insentif berdasarkan kinerja kemungkinan mempunyai hubungan dengan kinerja yang semakin tinggi pada perusahaanperusahaan dengan praktik pemanufakturan TQM. Berawal dari penelitian Sim dan Killough, permasalahan pokok yang akan diteliti pada studi ini yaitu menguji kembali apakah teknik pemanufakturan TQM dengan sistem pengukuran kinerja dan sistem penghargaan serta perilaku manajer yang biasanya digunakan sebagai variabel moderating serta interaksinya berpengaruh terhadap kinerja. Namun yang menjadi pembeda dalam studi ini dengan studi yang sebelumnya adalah pada variabel dan sampel yang digunakan. Variabel yang digunakan pada penelitian ini adalah pemanufakturan TQM, kinerja manajerial, sistem pengukuran kinerja, sistem penghargaan serta perilaku manajer. Sedangkan pada penelitian sebelumnya variabel yang digunakan adalah TQM, kinerja manajerial, sistem pengukuran kinerja, sistem penghargaan. Sampel yang digunakan dalam kegaiatan penelitian ini adalah manajer-manajer dari seluruh tingkatan manajemen yang bekerja di perusahaan manufaktur (perguruan tinggi di Malang yang menerapkan sistem kegiatan TQM dengan harapan bahwa manajer-manajer dari seluruh tingkatan manajemen dapat saling berinteraksi baik dengan karyawan maupun sesama manajer). Sedangkan pada penelitian sebelumnya sampel yang digunakan yaitu para manajer tingkat menengah pada perusahaān manufaktur.

\section{TINJAUAN PUSTAKA}

\section{Total Quality Managemen}

Total Quality Management (TQM) yaitu suatu cara untuk meningkatkan performasi yang dilakukan secara terus menerus atau berkelanjutan pada setiap tingkatan operasi maupun proses, pada setiap area fungsional atau tingkatan dari suatu organisasi dengan menggunakan semua Sumber Daya Manusia dan modal yang tersedia (Gasperz, 2002:6). Ada dua karakteristik utama TQM yaitu: (1). Berfokus pada upaya pemberian pelayanan kepada konsumen, dan (2). Upaya pemecahan permasalahan secara sistematik dengan menggunakan tim kerja garda depan (Garrison \& Noreen, 2000). Nama TQM pertama kali dikemukakan oleh Nancy Warren , seorang behavioral scientiat di United State Navy (Walton in Bounds, et. Al.,1994). TQM merupakan sistem manajemen berfokus pada seseorang maupun para tenaga kerja, yang bertujuan 
untuk secara terus menerus dalam meningkatkan nilai (value) yang bisa diberikan kepada pelanggan, dengan biaya yang penciptaan nilai yang lebih rendah (kecil) dari nilai tersebut (Bounds et. Al., 1994).

Mengacu apa dikutip Vincent Gasperz (ISO 8402 Quality Vocabulary, 200:6) TQM adalah suatu aktivitas dari berbagai fungsi manajemen organisasi secara keseluruhan, yang dapat menentukan suatu kebijaksanaan tentang kualitas, berbagai tujuan, dan tanggung jawab, serta melakukan implementasi melalui berbagai peralatan, seperti kegiatan pada perecanaan kualitas, pengendalian kualitas, jaminan kualitas, dan peningkatan kualitas. Menurut Tunggal (1993:9), TQM merupakan suatu kumpulan aktivitas yang bertujuan untuk melakukan perbaikan proses secara berkesinambungan (continous process improvement) yang bertujuan pada upaya kepuasan pelanggan (customer satisfaction). TQM berfokus pada para pelanggan. Tujuannya $\quad$ adalah memungkinkan suatu organisasi mengurangi berbagai bentuk pemborosan (wase), melakukan upaya penyederhanaan suatu proses, serta berfokus pada upaya penggunaan praktek mutu yang dapat dibuktikan, yang pada akhirnya dapat mempengaruhi pada setiap aktivitas yang dilaksanakan pada suatu organisasi. Sedangkan menurut Hardjosoedarmo (1996) yang dikutib dari Marijo dan Th. Sutadi (1997), TQM adalah penetapan metode kuantitatif atau pengetahuan tentang suatu kemanusiaan guna memperbaiki barang serta jasa yang menjadi input pada organisasi, melakukan upaya perbaikan pada semua proses penting di dalam suatu organisasi serta upaya perbaikan untuk memenuhi kebutuhan serta keinginan para pemakai produk dan jasa di masa sekarang atapun pada waktu mendatang.

Sebagaimana yang telah dikutip Gasperz (Jutan 2002:7) manajemen kualitas merupakan suatu kumpulan kegiatan atau aktivitas yang berkaitan dengan kualitas tertentu yang memiliki karakteristik sebagai berikut: menjadikan kualitas sebagai bagian penting dari setiap agenda manajemen atas, (2) Sasaran kualitas dimasukkan dalam rencana bisnis, (3) pencapaian sasaran diturunkan dari bench marking dengan fokus kepada pelanggan serta kesesuaian kompetisi dengan sasaran guna peningkatan kualitas tahunan, (4) Sasaran disebarkan ke level yang mengambil suatu tindakan, (5) pelatihan dilaksanakan untuk semua tingkatan. (6) Pengukuran ditetapkan seluruhnya, (7) Manajer tinglat atas secara periodik meninjau ulang kemajuan dengan membandingkan dengan target yang ditetapkan. (8) penghargaan diberikan pada kinerja yang terbaik, dan (9) sistem pemberian imbalan (reward system) selalu ada perbaikan.

\section{Penilaian Kinerja} Menurut menyatakan bahwa penentuan secara periodik operasional yang efektivit pada suatu- organisasi, termasuk bagian organisasi serta karyawannya berdasarkan pada sasaran, standar, serta kriteria yang ditetapkan sebelumnya. Informasi akuntansi dipergunakan sebagai landasan untuk menilai kinerja manajer karena informasi akuntansi menggambarkankan nilai sumber daya dasar untuk menilai kinerja manajer karena informasi akuntansi mencerminkan nilai untuk menjalankan suatu pengelolaan bisnis pada perusahaan. Kinerja manajer diwujudkan dalam berbagai kegiatan untuk mencapai tujuan perusahaan. oleh karena setiap bagian tersebut memerlukan adanya sumber daya, maka kinerja manajemen ditercerminkan dari setiap penggunaan sumber daya guna mencapai tujuan perusahaan yang telah ditetapkan. Tujuan utama pada penilaian kinerja adalah untuk memberikan motivasi para karyawan dalam upaya untuk mencapai sasaran organisasi serta dalam rangka untuk memenuhi standar aktivitas yang telah ditetapkan, agar menghasilkankan suatu tindakan serta hasil sesuai keinginan. Standar perilaku 49| P a g e 
dapat pula berupa suatu kebijakan manajemen atau rencana kegiatan formal yang dituangkan dalam suatu anggaran (Mulyadi, 2001). Penilaian kinerja dilakukan untuk mereduksi perilaku yang tidak diharapkan dan untuk mendorong serta menegakkan perilaku yang seharusnya dilakukan melalui berbagai umpan balik dari hasil kinerjanya (Mulyadi, 2001).

Manajer merupakan pelaksana kegiatan dalam suatu perusahaan. Tingkatan manajemen dalam perusahaan bila dihubungkan dengan aktivitas yang dilakukan oleh manajer terdiri adri tiga tingkatan yaitu (Mc Leod, 2001) menjelaskan manajer tingkat atas, Manajer level menengah serta bawah. Menurut Mc Leod (2001) pada saat melakukan rancangan sistem informasi penting untuk mempertimbangkan tingkatan manajer, karena hal ini dapat mempengaruhi sumber informasi serta bagaimana cara penyajiannya. Manajer pada level perencana strategis menekankan pada informasi terhadap lingkungan dari pada manajer tingkat yang lebih dibawahnya dan juga membutuhkan informasi dalam bentuk ringkas. Sedangkan untuk para manajer pada tingkatan pengendalian operasionalisasi menganggap bahwa informasi internal sebagai sesuatu yang lebih penting dan mereka lebih memilih informasi bentuk yang rinci. Peran manajer yang harus dipunyai oleh manajer dalam mendukung aktivitasnya (Garrison dan Norren, 2000) yaitu: keahlian manajemen, keahlian komunikasi, keahlian pemecahan masalah, dan pengetahuan manajemen. Manajer dapat menghasilkan kinerja dengan cara mengerahkan kemampuan dan bakat serta usaha para orang lain yang berada di area kewenangannya. Oleh karena itu, manajer memerlukan kerangka konseptual sebagai model kerja yang dapat digunakan sebagai alat komunikasi untuk menghasilkan kinerja manajerial (Mulyadi dan Setiawan, 2000). Kerangka konseptual kinerja manajerial adalah suatu struktur komponenkomponen yang membentuk kinerja orang yang memegang posisi manajerial (Mulyadi dan Setiawan, 2000).

\section{Sistem Pengukuran Kinerja}

Upaya penilaian terhadap suatu aktivitas (serta prosesnya) yang diselenggarakan adalah merupakan dasar yang melandasi upaya untuk meningkatkan pada kemampuan perusahaan dalam menghasilkan keuntungan. Pengukuran aktivitas kinerja dilakukan dalam bentuk keuangan serta non keuangan. Pengukuran ini didesain guna menilai bagaimana suatu aktivitas tersebut dilaksanakan dan hasil yang dicapai. Pengukuran aktivitas kinerja juga didesain untuk mengungkapkan apakah yang telah dilaksanakan pengembangan yang berkelanjutan terhadap suatu aktivitas untuk menghasilkan nilai bagi pelanggan. Pengukuran aktivitas kinerja berpusat pada 3 (tiga) dimensi, yaitu efisiensi, kualitas, serta waktu (Mulyadi dan Setyawan, 2000). Pengukuran terhadap kinerja mêrupakan salah satu faktor penting dalam upaya untuk mendorong daya saing sebuah usaha. Rancangan sistem pengukuran kinerja yang akurat serta konstektual merupakan langkah penting ke arah mana suatu keunggulan pada perusahaan akan dibawa. Ada 4 faktor utama yang harus diperhatikan dalam merancang sistem pengukuran kinerja, yaitu: (1) sudut pandang pihak yang memerlukan pengukuran; (2) level manajemen yang harus melakukan tanggung jawab terhadap pengukuran dan pelaporan; (3) pihak-pihak akan berpartisipasi dalam tindak lanjut terhadap hasil pengukuran kinerja; dan (4) frekuensi pengukuran yang dilaksanakan.

Pengukuran kinerja harus dilaporkan, dievaluasi, dan ditindak lanjuti berdasarkan waktu yang dibutuhkan (Wibisono, 1999:41). Program peningkatan kualitas yang menggunakan teknik TQM secara individual dikatakan efektif apabila perusahaan telah melakukan implementasi berbagai cara untuk memperbaiki kualitas secara terus menerus dibandingkan dengan perusahaan pesaing yang mengadakan 
pengembangan dengan tidak menggunakan teknik TQM, meskipun menyebabkan suatu pengurangan, atau setidaknya tidak ada peningkatan dalam kinerja (Drucker, 1990). Terdapat tiga macam pengukuran yang dapat digunakan untuk mengukur suatu kinerja secara kuantitatif (Mulyadi, 2001) ukuran dengan kriteria tunggal, ukuran dengan kriteria beragam, serta ukuran kriteria gabungan.

Dalam model aspek perilaku dalam motivasi individu menurut PorterLawyer, penghargaan tidak serta-merta memotivasi individu untuk mencapai sasaran yang telah ditetapkan. Untuk dapat memotivasi terhadap individu, pemberian penghargaan harus bisa dirasakan adil oleh individu yang bersangkutan. Jika penghargaan yang diterima oleh seseorang dirasakan adil, maka penghargaan ini akan memberikan kepuasan bagi orang tersebut (Mulyadi, 2001). Kompensasi merupakan bentuk return baik financial (baik berupa upah, gaji, bonus, komisi, asuransi, bantuan sosial, tunjangan, pemberian libur atau cuti dengan tetap dibayar) maupun non financial (tugas yang menarik, tantangan, tanggung jawab, pengakuan, peluang, pencapaian tugas, serta lingkungan pada pekerjaan yang menarik) yang diterima oleh karyawan atas jasa yang diberikankan kepada perusahaan (Kurnianingsih dan Indriantoro, 2001).

Menurut Walker (1992),

kompensasi merupakan salah satu bentuk strategi Manajemen Sumber Daya Manusia untuk dapat menciptakan adanya keselarasan kerja antara para staf dengan unsur pimpinan pada perusahaan dalam rangka untuk mencapai suatu tujuan dan sasaran yang sudah ditetapkan. Kinerja yang tinggi bisa dimungkinkan untuk dicapai jika praktik TQM digunakan bersama-sama dengan program peningkatan kinerja yang digunakan sebagai dasar untuk pemberian insentif (Sim dan Killough, 1998). Kinerja yang tinggi pada dasarnya tergantung pada program kegiatan pemberian insentif jika dihubungan dengan adanya pekerjaan yang juga mendukung, yaitu meliputi adanya penilaian kerja, insentif yang sama, dan adanya keamanan kerja (Ichniowski, 1997). Menurut Woolfolk, seperti yang telah dikutip oleh Ardhimas Krishna Nugraha (2002), reward merupakan peristiwa yang mengikuti tingkah laku dan meningkatkan kemungkinan untuk terulangnya kembali tingkah laku yang diinginkan. Reward ini memiliki efek positif maupun negatif. Efek positif dan reward adalah dapat mengukur perilaku dan meningkatkan kemampuan (Schunt, 1993).

Banyak cara yang bisa digunakan untuk membuat kategorisasi peranan manajerial dalam suatu organisasi. Siagian (1999) menjelaskan dari teori kepemimpinan dapat diketahui bahwa manajemen pada suatu organisasi memberikan tiga kategori peranan, yaitu (a). Peranan yang bersifat "Interpersonal", (b). Peranan informasional, dan (c) Peranan sebagai pengambil keputusan. Perilaku adalah cara membawa diri sendiri. Agan tercapai tujuan organisasi maka manusia yang ada di dalam suatu organisasi mestinya menjadi subyek bagi perkembangan organisasi tersebut. Manajemen puncak harus memperhatikan perilaku manajer dan seluruh anggota organisasi (Hussein, 1998). Perilaku manajer dibagi menjadi perilaku yang positif dan perilaku yang negatif. Perilaku positif (functional behavioral) diartikan sebagai dengan aturan yang telah ditetapkan (Syam dan Kusuma, 2001). Perilaku positif terjadi jika tujuan pribadi tiap-tiap angota organisasi sejalan dengan tujuan organisasi dan anggota organisasi tersebut mempunyai dorongan untuk mencapainya (Hussein, 1998). Sedangkan perilaku negatif (disfunctional behavior) adalah perilaku menyimpang yang tidak sesuai dengan ketentuan yang telah ditetapkan (Fazli Syam, 2001).

\section{Kerangka Pikir}

Dalam penelitian ini TQM diposisikan sebagai variabel independen, dimana variabel ini mempengaruhi baik secara positif maupun negatif terhadap 
variabel dependen. Apabila TQM bisa diterapkan secara efektif dalam suatu perusahaan (Perguruan Tinggi), maka kinerja manajerial dapat secara otomatis juga akan meningkat. Sedangkan sistem pengukuran kinerja dan sistem penghargaan serta perilaku manajer dalam penelitian ini merupakan variabel moderating yang mempunyai efek kesatuan hubungan pada variabel TQM sebagai variabel independen dan kinerja manajerial adalah sebagai variabel dependen.

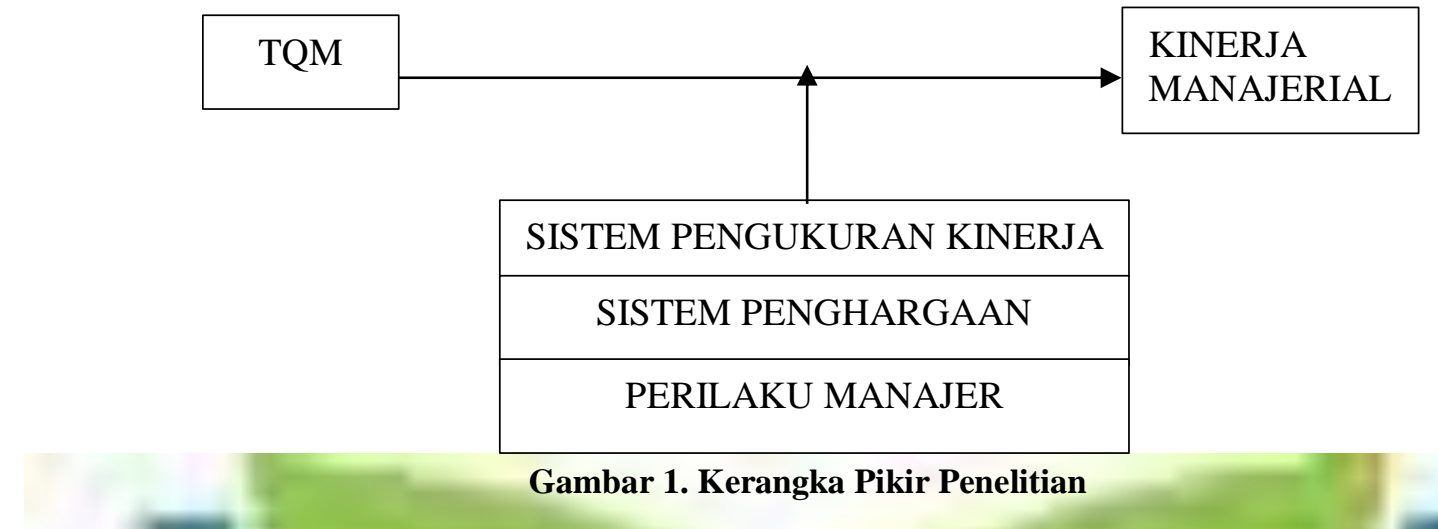

Hipotesis

$\begin{array}{lrr}\text { Menurut Sim dan } & \text { Killough } \\ \text { (1998), perusahaan yang } & \text { sudah } \\ \text { menerapkan teknik pemanufakturan TQM }\end{array}$ ternyata belum tentu dapat meningkatkan kinerja para karyawannya. Kemungkinan terdapat faktor lain yang menyebabkan praktik pemanufakturan tersebut dapat meningkatkan kinerja. Dengan demikian praktik pemanufaturan tersebut dapat meningkatkan kinerja. Dalam penelitian ini, komponen tersebut adalah suatu sistem pengukuran terhadap kinerja, sistem penghargaan, serta perilaku manajer. Penelitian ini bertujuan untuk menguji kembali interaksi antara TQM dengan sistem pengukuran suatu kinerja yang berpengaruh secara positif serta signifikan terhadap suatu kinerja manajerial. Hipotesis yang dimunculkan pada penelitian ini adalah:

H1 : Interaksi antara teknik TQM dan sistem pengukuran kinerja akan berpengaruh yang positif terhadap kinerja manajerial.

H2 : Interaksi antara teknik TQM dan sistem penghargaan akan berpengaruh yang positif terhadap kinerja manajerial.

H3 : Interaksi antara teknik TQM dan perilaku manajer akan berpengaruh yang positif terhadap kinerja manajerial.

\section{METODE PENELITIAN}

Jenis penelitian ini digunakan adalah penelitian dengan pendekatan kuantitatif dengan menggunakan analisis eksplanasi. Metode yang digunakan adalah survey dengan pengumpulan data menggunakan daftar pertanyaan untuk mengambil sampel dari suatu populasi, dengan analisis data bersifat kantitatif yang bertujuan untuk melakukan pengujian hipotesa yang telah ditetapkan. Jenis data yang digunakan dalam kegiatan penelitian ini adalah data kuantitatif, sumber data yang digunakan data primer dan skunder.

Populasi untuk penelitian ini adalah para manajer (pimpinan atas sampai dengan menengah) pada perguruan Tinggi, dan Dosen (non structural) serta karyawan sebagai feedback yang menerapkan teknik TQM dengan pertimbangan bahwa perguruan tinggi yang melaksanakan proses pembelajaran dan layanan, dan khususnya di Malang yang menerapkan TQM. Populasi dalam penelitian ini adalah pimpinan atas sampai dengan menengah, berserta para karyawan dan dosen non structural, sedangkan sampelnya yang digunakan adalah pimpinan atas sampai dengan menengah, beserta dosen non structural dan karyawan (sebagai feed back), kuesioner yang terkumpul adalah 40 kuesioner dengan respon. Teknik 
penentuan sampel dalam penelitian ini adalah teknik Purposive Sampling.

Variabel dalam penelitian ini meliputi: variabel terikat: yaitu kinerja manajerial, variabel bebas: yaitu total quality management serta variabel moderating; yaitu sistem pengukuran kinerja dan sistem sistem penghargaan serta perilaku manajer. Teknik analisis data yang digunakan moderated regresion analysis yang merupakan aplikasi khusus dari regresi linier berganda, dimana pada persamaan regresinya mengandung adanya unsur interaksi (Ghozali, 2006).

Untuk menguji Hipotesa yaitu Pengaruh Tehnik TQM, interaksi antara TQM dengan Sistem Pengukuran Kinerja terhadap Kinerja Manajerial, interaksi antara TQM dengan Sistem Penghargaan terhadap Kinerja Manajerial, dan intaraksi antara TQM dengan perilaku manajer terhadap kinerja manajerial dengan persamaan regresi melalui uji interaksi yaitu merupakan aplikasi khusus pada abalisis regresi linier berganda dimana persamaan regresinya mengandung unsur adanya interaksi (perkalian dua atau lebih pada variabel independent (Ghozali, 2006).

\section{HASIL DAN PEMBAHASAN}

Responden dalam kegiatan penelitian ini berjumlah 40 responden, dari jumlah tersebut 4 diantaranya tidak menjawab dengan lengkap dan tidak menyertakan data diri secara lengkap. Berdasarkan data yang diperoleh $27,8 \%$ responden adalah pria dan $72,2 \%$ responden adalah wanita. Hal ini berarti posisi memanaj pada perguruan tinggi yang diteliti masih didominasi oleh wanita. Kisaran usia responden pada penelitian ini antara 47 tahun sampai dengan 65 tahun. Pengelompokkan responden secara lebih rinci dapat dilihat dalam tabel 1

Tabel 1. Deskripsi Responden

\begin{tabular}{cccc}
\hline Umur & $\begin{array}{c}\text { Jenis kelamin } \\
\text { Pria }\end{array}$ & $\begin{array}{c}\text { Jenis Kelamin } \\
\text { Wanita }\end{array}$ & Total \\
\hline$<50^{\text {th }}$ & 4 & 6 & 10 \\
\hline $50^{\text {th }}$ & 7 & 19 & 26 \\
\hline Total & 11 & 25 & 36 \\
\hline Tabel 2.Pengalaman menjabat pimpinan & Pria & Wanita & Total \\
\hline Lama & 4 & 8 & 12 \\
\hline$<4^{\text {th }}$ & 6 & 18 & 24 \\
\hline$>4^{\text {th }}$ & 10 & 26 & 36
\end{tabular}

Sumber : data primer diolah 2018

Uji Validitas data penelitian ini ditentukan oleh adanya proses pengukuran yang akurat (Indriantoro \& Supomo, 2000:181) uji validitas digunakan untuk meunjukkan sejauh mana suatu alat pengukur itu dapat mengukur apa yang hendak diukur. Hasil pengujian validitas terhadap ketiga variabel penelitian tersebut dinyatakan valid yang ditujukan pada tabel tersebut, menunjukkan $\mathrm{r}$ hitung untuk semua variabel penelitian yaitu TQM, Sistem Pengukuran Kinerja, Sistem
Penghargaan serta Perilaku Manajer semuanya lebih besar daripada $r$ tabel. Hasil tersebut menunjukkan bahwa item kuesioner pada penelitian ini valid.

Reliabilitas adalah indeks yang digunakan untuk menunjukkan sejauh mana suatu alat pengukur dapat dipercaya atau dapat diandalkan. Cara menghitung tingkat reliabilitas suatu data yaitu menggunakan rumus Cronchbach's alpha. Hasil pengujian reliabilitas terhadap ketiga variabel penelitian terangkum dalam tabel berikut: 


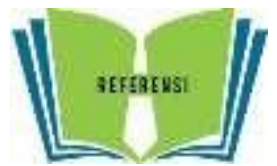

ISSN: 2089-0532, e-ISSN: 2548-6152

Tabel 3. Hasil Pengujian Reliabilitas

\begin{tabular}{ccc}
\hline Variabel & Alpha & Keterangan \\
\hline TQM & 0,8032 & Reliabel \\
\hline Sistem Pengukuran kinerja & 0,8074 & Reliabel \\
\hline Perilaku Manajer & 0,9166 & Reliabel \\
\hline Kinerja manajerial & 0,8636 & Reliabel
\end{tabular}

Sumber: data primer diolah 2018

Tabel 3 menunjukkan nilai alpha $(\alpha)$ untuk semua variabel penelitian yaitu (TQM), sistem pengukuran pada kinerja, sistem penghargaan, perilaku manajer, dan kinerja manajerial semuanya mendekati nilai satu. Hasil tersebut membuktikan bahwa kuesioner yang dipergunakan pada penelitian ini reliabel. Untuk memberikan suatu gambaran mengenai variabel penelitian yaitu TQM, Sistem Pengukuran Kinerja, Sistem Penghargaan, Perilaku Manajer, dan Kinerja Manajerial), peneliti mempergunakan tabel distribusi frekuensi absolut yang mampu menunjukkan angka rata-rata, kisaran teoritis, kisaran aktual dan standar deviasi. Analisa ini didasarkan pada 36 jawaban responden tentang variabel penelitian. Hasil analisa ini dapat dilihat di tabel 4. Selain itu juga diuraikan besarnya TQM, Sistem Pengukuran Kinerja, Sistem Penghargaan, Perilaku Manajer, dan Kinerja Manajerial yang dapat dilihat di tabel 4.

Tabel 4. Deskripsi Statistik Variabel TQM, Sistem Pengukuran Kinerja, Sistem Penghargaan, Perilaku Manajer, dan Kinerja Manajerial

\begin{tabular}{lcccc}
\hline \multicolumn{1}{c}{$\begin{array}{c}\text { VARIABEL } \\
\text { TQM }\end{array}$} & RATA2 & STD.DEVIASI & $\begin{array}{c}\text { KISARAN } \\
\text { AKTUAL }\end{array}$ & $\begin{array}{c}\text { KISARAN } \\
\text { TEORITIS }\end{array}$ \\
\hline $\begin{array}{l}\text { SIST.PENGUKURAN } \\
\text { KINERJA }\end{array}$ & 17,28 & 2,63 & $12-21$ & $3-21$ \\
\hline SIST.PENGHARGAAN & 10,67 & 1,31 & $8-14$ & $2-14$ \\
\hline PERILAKU MANAJER & 8,81 & 0,40 & $0-1$ & $0-1$ \\
\hline KINERJA MANAJERIAL & 50,81 & 12,10 & $59-61$ & $61-112$ \\
\hline
\end{tabular}

Sumber : data primer yang diolah, 2018

Tabel 5. Tingkatan Persepsi Responden

\begin{tabular}{lcccc}
\hline \multicolumn{1}{c}{ Variabel } & Mean & Tinggi & Sedang & Rendah \\
\hline TQM & 17,28 & $15,01-21,00$ & $9,01-15,00$ & $3-9,00$ \\
\hline SIST.PENGK.KINERJA & 10,67 & $10,01-14,00$ & $6,01-10,00$ & $2-6,00$ \\
\hline SIST.PENGHARGAAN & 0,81 & $1,34-2,00$ & $0,67-1,33$ & $0-0,66$ \\
\hline PERILAKU MANAJER & 82,75 & $80,01-112,00$ & $48,01-80,00$ & $16-48,00$ \\
\hline KINERJA MANAJERIAL & 50,81 & $45,01-63,00$ & $27,01-45,00$ & $9-27,00$ \\
\hline
\end{tabular}

Sumber: Data Primer Diolah 2018

Berdasarkan tabel 4 hasil pengukuran variabel Total Quality Management dengan menggunakan 3 item pertanyaan yang dikembangkan oleh Snell dan Dean (1992), memperlihatkan bahwa manajer yang menjadi responden ada yang merasa bahwa penerapan teknik TQM sangat membantu sekali dalam pelaksanaan aktivitasnya, yang ditunjukkan oleh jumlah skor tertinggi dari kisaran aktual yaitu
21 yang nilainya sama dengan kisaran teoritis tertinggi. Selain itu skor kisaran aktual terendah untuk variabel ini adalah 12. Hal ini menunjukkan bahwa dengan penerapan total quality management cukup membantu manajer dalam melaksanakan aktivitasnya. berdasarkan tabel 5 tampak bahwa rata-rata skor total quality management berada pada skala tinggi berarti penerapan total quality 
management cukup membantu dalam pelaksanaan aktivitas para manajer.

Pengukuran variabel Sistem Pengukuran Kinerja dengan menggunakan 2 item pertanyaan yang dikembangkan oleh Daniel dan Reitsperger (1992) pada tabel 5 menunjukkan skor rata-rata sistem pengukuran kinerja berada dalam skala yang tinggi. Hal ini berarti sistem pengukuran kinerja yang dialami oleh para manajer umumnya tinggi. pengukuran variabel sistem penghargaan yang menggunakan 1 item pertanyaan yang dikembangkan oleh Ittner dan Larcker (1995), pada tabel 4 menunjukkan bahwa ada responden yang merasa bahwa sistem penghargaan sangat berpengaruh dalam pelaksanaan aktivitasnya. Berdasarkan tabel 5 menunjukkan bahwa skor rata-rata Sistem Penghargaan berada dalam skala sedang.

Pengukuran variabel Perilaku Manajer yang menggunakan 16 item pertanyaan yang dikembangkan oleh Ferrel dan Skinner (1998), pada tabel 5 menunjukkan bahwa rata-rata skor Perilaku Manajer dalam skala tinggi. Hal ini berarti perilaku para manajer sangat tinggi. Pengukuran variabel Kinerja Manajerial dengan self-rating yang menggunakan 9 item pertanyaan yang dikembangkan oleh Mahoney, et al (1963), pada tabel 4 menunjukkan adanya responden yang mempunyai kinerja sangat baik atau skala kinerja tinggi dan tidak ada responden yang mempunyai skala kinerja rendah. Sedangkan dari skor rata-rata pada jawaban responden pada tabel 5 tampak bahwa kinerja manajerial berada dalam skala tinggi.

Penelitian ini bertujuan untuk menguji secara empiris apakah terdapat adanya pengaruh yang positif serta signifikan dalam interaksi total quality management sebagai variabel independen dan sistem pengukuran, sistem penghargaan serta perilaku manajer sebagai bentuk variabel moderating terhadap kinerja manajerial sebagai variabel dependen. Untuk menemukan bukti empiris dilakukan uji regresi linier berganda dengan satu persamaan regresi. Analisis regresi linier berganda* ini dihitung dengan menggunakan program SPSS (Statistical Package for Social Science) dan menggunakan model persamaan regresi.

Tabel 6. Hasil Regresi

\begin{tabular}{ccccc}
\hline VARIABEL & KOEFISIEN(B) & KESALAHAN STANDARD & $\mathrm{t}$ & Sig \\
\hline KONSTANTA & 88,447 & 69,150 & 1,279 & 0,211 \\
\hline TQM & $-3,464$ & 4,084 & $-0,848$ & 0,404 \\
\hline SPK & $-15,521$ & 6,335 & $-2,450$ & 0,021 \\
\hline SP & $-20,665$ & 17,681 & $-1,169$ & 0,252 \\
\hline PM & 1,443 & 0,660 & 2,186 & 0,037 \\
\hline TQM dan SPK & 1,002 & 0,369 & 2,720 & 0,011 \\
\hline TQM dan SP & 1,412 & 1,061 & 1,332 & 0,194 \\
\hline TQM dan PM & $-8,38 \mathrm{E}-02$ & 0,039 & $-2,125$ & 0,043 \\
\hline
\end{tabular}

$\mathrm{R}^{2}=0,572 ;$ Adjusted $\mathrm{R}^{2}=0,465 ; \mathrm{n}=36 ; \mathrm{F}=5,350 ;$ Sig $\mathrm{F}=0,001$

Sumber : data primer diolah 2018

Besarnya kontribusi atau pengaruh variabel independen pada variabel dependen untuk masing-masing model regresi digunakan adjusted $\mathrm{R}^{2}$. Pada hasil perhitungan regresi linier berganda untuk interaksi antara TQM serta sistem pengukuran kinerja terhadap kinerja manajerial diperoleh besarnya koefisien determinasi (adjusted $\mathrm{R}^{2}$ ) adalah 0,465.
Artinya interaksi antara TQM serta variabel moderating terhadap kinerja manajer mempunyai pengaruh sebesar $46,5 \%$.

Pengujian hipotesis ini menggunakan tingkat signifikansi. Bila sig $\mathrm{t}<\alpha(0.05)$ maka Ha diterima dan bila sig $\mathrm{t}>\alpha$ (0.05) maka Ha ditolak. Berdasarkan hasil regresi berganda yang disajikan pada tabel 6 , menujukkan bahwa interaksi antara TQM dan sistem 
pengukuran kinerja menunjukkan koefisien positif sebesar 1,002 dengan tingkat signifikansi kurang dari 0,05 terhadap kinerja manajerial $(0,011)$, artinya hubungan Sistem Pengukuran Kinerja mempunyai pengaruh moderating terhadap hubungan TQM dan Kinerja Manajerial. Untuk menentukan apakah Ha1 akan diterima atau ditolak, dilakukan dengan cara menentukan apakah interaksi antara TQM dan sistem pengukuran kinerja signifikan atau tidak. Berdasarkan hasil pengolahan, ditemukan bahwa interaksi antara TQM dan sistem pengukuran kinerja signifikan, maka dengan demikian Ha1 diterima dan Ho1 ditolak.

$$
\text { Berdasarkan hasil regresi }
$$

berganda yang disajikan pada tabel 6 bahwa interaksi antara dan Sistem Penghargaan menunjukkan koefisien positif $(1,412)$ dengan tingkat signifikansi lebih dari 0,05 terhadap kinerja manajerial $(0,194)$, artinya Ha2 ditolak dan $\mathrm{Ho} 2$ diterima karena tidak terdapat pengaruh yang positif serta signifikan dalam interaksi antara TQM dan Sistem Penghargaan terhadap Kinerja Manajerial.Hasil hipotesis ini mendukung penelitian yang dilakukan oleh Ittner \& Larcker (1995) yang tidak menemukan bukti bahwa organisasi yang mempraktekkan TQM dan Sistem pengukuran manajemen secara interaktif dapat mencapai kinerja financial dan kualitas yang baik (tinggi).

Selanjutnya berdasarkan hasil regresi berganda yang disajikan dalam pada 6 bahwa interaksi antara TQM dan perilaku manajer menunjukkan koefisien negatif sebesar - 0.00838 dengan tingkat signifikansi kurang dari 0,05 terhadap kinerja manajerial $(0,043)$, artinya tidak terdapat pengaruh yang positif serta signifikan dalam interaksi antara TQM dan perilaku manajer terhadap kinerja manajerial. Variabel perilaku manajer memperlemah hubungannya terhadap variabel TQM, karena nilai koefisien yang negatif (-0.00838). Maka dengan demikian Ha3 ditolak dan Ho3 diterima.

\section{KESIMPULAN}

Berdasarkan dari hasil analisis data dengan analisis regresi berganda dalam penelitian ini dapat disimpulkan bahwa nilai koefisien TQM dan Sistem Pengukuran Kinerja positif (koef. TQM dan SPK >0) dan nilai sig. $\mathrm{t}(0,011)<0,05$, yang berarti Ha1 diterima dan Hol ditolak. Berarti terdapat pengaruh yang signifikan dalam interaksi antara TQM dan Sistem Pengukuran Kinerja terhadap Kinerja Manajerial. Sedangkan berdasarkan hasil interaksi antara TQM dan Sistem Penghargaan menunjukkan koefisien positif sebesar 1,412 dengan tingkat signifikansi lebih dari 0,05 terhadap kinerja manajerial $(0,194)$ yang berarti $\mathrm{Ha} 2$ ditolak dan Ho2 diterima. Berarti interaksi antara TQM dan Sistem Penghargaan terhadap Kinerja Manajerial tidak signifikan. Sedangkan berdasarkan hasil interaksi antara TQM dan Perilaku Manajer menunjukkan koefisien negatif sebesar - 0.00838 dengan tingkat signifikantsi kurang dari 0,05 terhadap kinerja manajerial $(0,043)$ yang berarti Ha3 ditolak dan $\mathrm{Ho} 3$ diterima. Berarti ada pengaruh negatif tetapi signifikansi dalam interaksi antara TQM dan Perilaku Manajer terhadap Kinerja Manajeria

$$
\text { Untuk penelitian selanjutnya, }
$$
peneliti menyarankan untuk menambahkan atau mengganti variabel lain yang dapat mempengaruhi kinerja manajerial selain TQM, sistem pengukuran kinerja, sistem penghargaan, dan perilaku manajer. Untuk penelitian selanjutnya dapat dilakukan dengan cara mengambil sampel yang berbeda misalnya perusahaan manufaktur besar di Indonesia atau perusahaan manufaktur yang sudah mendapatkan serifikat ISO. Selain itu juga perlu untuk mengembangkan lagi pertanyaan untuk TQM, sistem pengukuran kinerja, sistem penghargaan, serta perilaku manajer karena penelitian tersebut dan pengaruhnya di bidang akuntansi manajemen masih belum banyak dilakukan. 


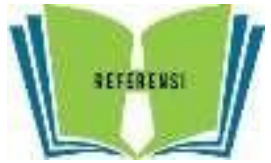

ISSN: 2089-0532, e-ISSN: 2548-6152

\section{DAFTAR PUSTAKA}

Anthony, Robert N. dan Vijay Govindrajan, 2002, Sistem Pengendalian, terjemahan Kurniawan Tjakrawala, Buku 1, Jakarta : Salemba Empat

Cristina, Dian, 2004, Pengaruh Sistem Pengukuran Kinerja dan Sistem Penghargaan Terhadap Keefektifan Penerapan Teknik TQM (Studi Empiris Pada Perusahaan Manufaktur di Semarang), Skripsi, Semarang: Fakultas Ekonomi Unika Soegijapranata (tidak diterbitkan)

Ghozali, I, 2002, Aplikasi Analisis Multivariate dengan Program SPSS, Semarang: Badan Penerbit: 1091 UNDIP

Indriantoro, Nur dan Bambang Supomo, 1999, Metodologi Penelitian Bisnis Untuk Akuntansi \& Manajemen, Yogyakarta: BPFE

Ittner, D, dan D. F. Larcker, 1995, TQM and The Choice of Information and Reward System, Journal for Accounting Research : hal 1-34

Kurnianingsih, Retno, dan Indriantoro, Nur, 2001, "Pengaruh Sistem Pengukuran Kinerja dan Sistem Penghargaan Terhadap Keefektifan Penerapan Teknik Total Quality Management", Jurnal Riset Akuntansi : hal 28-43

Maridjo, H. Herry dan Th. Sutadi, 1997,

"Dasar dan Konsep Total Quality Management (TQM)", Widya Dharma, Oktober 1997: hal 13-27

Mcleod, Raymond, 2001, Sistem Informasi Manajemen, edisi ketujuh, Jakarta : PT. Prenhallindo

Mulyadi, 2000, TQM : Prinsip Manajemen

Kontemporer Untuk Mengarungi Lingkungan Bisnis Global, Yogyakarta : Adity Media

Mulyadi, 2001, Akuntansi Manajemen : Konsep, Manfaat, dan Rekayasa, edisi ketiga, Jakarta : Salemba Empat

Mulyadi, dan Johny Setiawan, 2000, Sistem Perencanaan dan
Pengnedalian Manajemen : Sistem Pelipat Ganda, Kinerja Perusahaan, edisi kesatu cetakan pertama, Jakarta : Rineka Cipta

Rifa'i, Muhamad, 2009, Hubungan antara gaya kepemimpinan, budaya organisasi, Motivasi berprestasi, dan komitemen pada organisasi dengan kinerja dosen pada Universitas dalam Pesantren di Jawa Timur, Disertasi, Universitas Negeri Malang. http://karyailmiah.um.ac.id/index.php/disertasi /article/view/2418

Siagian, Sondang P,1999, Sistem Informasi Manajemen, Jakarta : Bumi Aksara

Suhartono, 2000, "Perilaku Manajer dan Pengaruhnya Terhadap Peningkatan Kinerja Karyawan", Kajian Bisnis: hal 65-73

Supriyono, 1993, kuntansi Manajemen I edisi 1, Yogyakarta : BPFE Swastha, Basu, 2000, Azas-azas Manajemen Modern, Yogyakarta : Liberty

Fazli, BZ dan Kusuma, Indra Wijaya, 2001, "Pengaruh Informasi Akuntansi dan Ketidakpastian Tugas terhadap Perilaku Manajer : Sebuah Eksperimen Semu”, Jurnal Riset Akuntansi : hal 314-328

Umar, Husein, 1998, Riset Akuntansi, Jakarta: PT. Gramedia Pustaka Umum

Wibisono, Dermawan, 1999, Analisis Keterkaitan Variabel Kinerja Dalam Perusahaan: Usahawan

Widjaja Tunggal, AK, MBA, 1993, Manajemen Mutu Terpadu Suatu Pengantar Total Quality Management, cetakan pertama, Jakarta: Rineka Cipta 